\title{
Invasive candidiasis serological diagnosis in solid organ transplant recipients
}

\author{
KATARZYNA PISKORSKA ${ }^{1}$, MAGDALENA SIKORA², MARLENA GOEAŚ', MARIA DĄBKOWSKA², \\ LESZEK PACZEK $K^{3}$ EWA SWOBODA-KOPEC $C^{2}$
}

${ }^{1}$ Department of Medical Microbiology, Medical University of Warsaw, Warsaw, Poland

${ }^{2}$ Department of Dental Microbiology, Medical University of Warsaw, Warsaw, Poland

${ }^{3}$ Department of Immunology, Transplantology and Internal Medicine, Institute of Transplantology,

Medical University of Warsaw, Warsaw, Poland

\begin{abstract}
Solid organ transplant recipients are at high risk of fungal infections, because of ongoing immunosuppressive treatment. There are three post organ transplant phases: early, intermediate, and late, all of them at risk of Candida infections. Since conventional tests are insufficient, specific secondary diagnostic tests are still being explored. Serological tests are currently the most common choice. The present study was to determine the usefulness of mannan antigen and anti-mannan antibody detection in diagnosing invasive candidiasis in liver or kidney transplant recipients. The levels of mannan and anti-mannan antibodies were assessed with Platelia Candida Ag Plus, and Platelia Candida Ab Plus (Biorad, Marne-la-Coquette, France) commercial tests, according to manufacturer's guidelines. Sixty six serum samples were obtained from 25 patients (9 liver transplant recipients, 7 kidney transplant recipients, and 9 patients prepared for a kidney transplant), 29 serum samples from 15 patients tested positive for mannan antigen. Serum samples were obtained from 14 patients tested positive for anti-mannan antibodies. Fungal antigen detection in blood serum in patients under immunosuppression, especially with neutropenia, suggests that antifungal treatment should be administered. Serological tests, especially mannan and anti-mannan ones, are very useful for confirmation or exclusion of invasive candidiasis in high-risk patients.
\end{abstract}

Key words: antigen, antibody, serological tests.

(Centr Eur J Immunol 2014; 39 (2): 187-192)

\section{Introduction}

Fungal infections in solid organ transplant recipients are difficult to diagnose and treat. This type of infection is related, among others, to the type of the transplanted organ. Invasive candidiasis occurs more often in liver recipients, and invasive aspergillosis in lung recipients [1-3]. Invasive candidiasis is one of the main post transplant complications, presenting a high risk of death. There are three phases, depending on the time since transplant: early (1 month after transplant), intermediate (2-6 months), and late (> 6 months). There might be different types of complications, because of different risk factors depending on how long ago the transplant was performed. Every phase carries different risk factors for invasive candidiasis. Invasive candidiasis is a risk in the early, intermediate and late phase, however, each phase is characterised by different predisposing factors $[1,3]$. Rapid and precise fungal infection diagnosis and appropriate antifungal treatment administration are crucial in post transplant patients.
Tests confirming diagnosis are being developed because of the difficulty in detecting fungal infections, because of scarce and unspecific symptoms, and because of insufficient sensitivity and specificity of classical methods [1, 4]. Besides classical/culture methods, new ones to detect yeast infections, such as highly immunogenic components of yeast cell walls - mannan [Platelia Candida Ag PLUS (Biorad, Marne-laCoquette, France)], and also (1-3)- $\beta$-D-glucan (such as Fungitec-G, Glucatell - Fungitell), are being researched $[2,5,6]$. Rapid serological tests seem useful to monitor the physical condition of patients at high risk of fungal infections, and also make it possible to quickly detect them $[6,7]$. Cell wall components are transient and rapidly taken up by endocytosis or by the forming immune complexes in invasive infections. For practical reasons, it is advisable to regularly monitor the levels of those markers in body fluids in high-risk patients [6]. The simple detection of yeast cell wall components does not provide any information on strain antimycotic susceptibility. It is above all important in infections with strains resistant to basic antimycotics.

Correspondence: Katarzyna Piskorska, Department of Medical Microbiology, Medical University of Warsaw, Chałubińskiego 5, 02-004 Warsaw, Poland, tel./fax +48 2262827 39, e-mail: kaspiskorska@gmail.com 
With mannan, a polysaccharide antigen with strong immunogenic and immunomodulatory properties, it was possible to come up with a new strategy of invasive candidiasis detection. It focuses on simultaneously monitoring the levels of circulating mannan and anti-mannan antibodies in patients at risk of invasive candidiasis. This strategy increases the chances of detecting invasive infections, since a high mannan level is related to a decrease in anti-mannan antibodies [6]. That was confirmed in the Sendid et al. study, where a single identification of mannan or anti-mannan antibodies detected the infection in $40-50 \%$ of individuals [8]. Simultaneous testing for these two markers resulted in an $80 \%$ increase in sensitivity and $93 \%$ increase in specificity in the same patients [8].

As it was proven by Sendid et al., simultaneous testing for mannanaemia and anti-mannan antibodies in diagnosing invasive candidiasis, especially in immunocompetent patients, increased the chances of detecting an infection $[7,8]$. Research data related to the afore-mentioned parameters are scarce. Sendid et al. investigated their correlation in patients presenting invasive candidiasis symptoms, but no neutropenia symptoms [2, 4, 7]. Despite quite thorough descriptions of the importance of testing for mannan and anti-mannan antibodies in bone-marrow transplant recipients, there is still little information about the usefulness of these tests in surgical and transplant patients, especially because of the administered immunosuppression. It could become a helpful parameter in diagnosing invasive candidiasis in recipients with stable organ transplants and without additional aggravations [1].

However, these tests are most sensitive with Candida albicans, C. glabrata, and C. tropicalis infections. For C. krusei, C. parapsilosis, and C. guillermondii infections, the sensitivity is only of $40-50 \%[6,7,9]$.

Since so little is known about the usefulness of mannan antigen and anti-mannan antibodies testing, the idea was to try assessing the usefulness of this test in surgical and transplant patients.

The present study was to determine the usefulness of mannan antigen and anti-mannan antibody testing in diagnosing invasive candidiasis in liver/kidney transplant recipients.

\section{Material and methods}

The present study was retrospective. Twenty-five patients were selected and had serum samples collected at least twice, as part of routine diagnostic procedures, and additionally were examined for clinical symptoms of fungal infections, had their fungal prevention routines assessed, and fungi were cultured out of various clinical materials, including blood.

Mycological tests were performed on 66 clinical samples from 25 patients hospitalised at the Warsaw Teaching Hospital in 2011-2012. Additionally, 35 clini- cal samples collected from those patients were analysed during that period of time as part of routine mycological diagnostic procedures, including blood (4), BAL (4), sputum (5), and urine (4); other materials included: throat swab, fluid after liver re-transplantation, aortic abscess, wounds, drains, samples of tissues, peritoneal fluid, anal swabs, stool samples, and 66 blood serum samples. The clinical material was collected during routine diagnostic procedures from patients hospitalised at the Warsaw Medical University Institute of Transplantology in 2011-2012.

Strains were cultured on Sabouraud agar with chloramphenicol for $24-48$ hours at $30^{\circ} \mathrm{C}$, and then on CHROMagar Candida media (Graso Biotech, Starogard Gdanski, Poland). Strain identification was performed using biochemical traits with the automated ID $32 \mathrm{C}$ test (BioMeriéux, Marcy l'Etoile, France) according to manufacturer's guidelines.

All collected serum samples were stored at $-20^{\circ} \mathrm{C}$ before testing, according to test manufacturer's guidelines. The levels of mannan and anti-mannan antibodies were assessed with Platelia Candida Ag Plus, and Platelia Candida Ab Plus (Biorad, Marne-la-Coquette, France) commercial tests, according to manufacturer's guidelines. Result interpretation followed manufacturer's mannan cutoffs: negative $<62.5 \mathrm{pg} / \mathrm{ml}$; positive $>125 \mathrm{pg} / \mathrm{ml}$, for anti-mannan antibodies: negative $<5 \mathrm{AU} / \mathrm{ml}$; positive $>10 \mathrm{AU} / \mathrm{ml}$.

\section{Results}

After analysing 66 serums from 25 patients (9 liver transplant recipients, 7 kidney transplant recipients, and 9 patients prepared for a kidney transplant), 29 serum samples from 15 patients tested positive for mannan antigen. Thirty-one serum samples from 14 patients presented a high level of anti-mannan antibodies. Eleven serum samples from 7 patients presented a high level of both soluble mannan antigen and anti-mannan antibodies. In those patients, Candida spp. yeasts were cultured in three of those samples. Candida spp. was also cultured in different clinical material from 11 patients with a high mannan antigen or anti-mannan antibody levels.

Table 1 presents the results of the study.

\section{Discussion}

Fungal infections often develop in organ transplant recipients. The biggest percentage of fungal infections occurs in bone marrow transplants, more rarely in liver transplants, most rarely in kidney transplants. Invasive fungal infections in those groups are a diagnostic and therapeutic challenge. Mycological tests, including sample microscopy analysis, culture on different media, and identification using biochemical traits, are still insufficient to detect fungal infections $[3,10]$. 
Table 1. Results and their clinical interpretation

\begin{tabular}{|c|c|c|c|c|c|c|}
\hline $\begin{array}{l}\text { Patient } \\
\text { number }\end{array}$ & $\begin{array}{c}\text { Mannan antigen } \\
\text { levels }\end{array}$ & $\begin{array}{c}\text { Anti-mannan } \\
\text { antibody levels }\end{array}$ & $\begin{array}{l}\text { Transplanted } \\
\text { organ }\end{array}$ & Fungal culture & $\begin{array}{c}\text { Antifungal } \\
\text { prophylaxis }\end{array}$ & $\begin{array}{c}\text { Clinical } \\
\text { interpretation }\end{array}$ \\
\hline \multirow[t]{3}{*}{ I } & 33.8 & 7.0471 & \multirow[t]{3}{*}{ kidney } & \multirow{3}{*}{$\begin{array}{l}\text { C. albicans }- \text { sputum, } \\
\text { C. glabrata }- \text { sputum, } \\
2 \times \text { C. tropicalis }- \text { sputum }\end{array}$} & \multirow[t]{3}{*}{-} & \multirow[t]{3}{*}{ possible IC } \\
\hline & 62.8 & 6.8297 & & & & \\
\hline & 51.1 & 6.1957 & & & & \\
\hline \multirow[t]{2}{*}{ II } & 304.87 & 50.648 & \multirow{2}{*}{$\begin{array}{l}\text { prepared for a kidney } \\
\text { transplantation }\end{array}$} & no culture & \multirow[t]{2}{*}{ fluconazole } & \multirow[t]{2}{*}{ probable IC } \\
\hline & 71.8 & 20.751 & & & & \\
\hline \multirow[t]{2}{*}{ III } & 358 & 5.217 & \multirow[t]{2}{*}{$\begin{array}{l}\text { prepared for a kidney } \\
\text { transplantation }\end{array}$} & $\begin{array}{c}2 \times \text { C. albicans }-\mathrm{BAL} \\
\text { urine }\end{array}$ & \multirow[t]{2}{*}{ itraconazole } & \multirow[t]{2}{*}{ possible IC } \\
\hline & 38.1 & 3.2353 & & & & \\
\hline \multirow[t]{2}{*}{ IV } & 308.7 & 4.2647 & \multirow[t]{2}{*}{ kidney } & C. albicans - blood & \multirow[t]{2}{*}{ voriconazole } & \multirow[t]{2}{*}{ proven IC } \\
\hline & 181.1 & 53.72 & & & & \\
\hline \multirow[t]{2}{*}{$\mathrm{V}$} & 66.8 & 2.8824 & \multirow[t]{2}{*}{ kidney } & no culture & \multirow[t]{2}{*}{ fluconazole } & \multirow[t]{2}{*}{ probable IC } \\
\hline & 86.8 & 14.435 & & & & \\
\hline \multirow[t]{2}{*}{ VI } & 55.7 & 0.17647 & \multirow{2}{*}{$\begin{array}{l}\text { prepared for a kidney } \\
\text { transplantation }\end{array}$} & no culture & \multirow[t]{2}{*}{-} & \multirow[t]{2}{*}{ excluded IC } \\
\hline & 67.5 & 0 & & & & \\
\hline \multirow[t]{2}{*}{ VII } & 469.7 & 7.9891 & \multirow[t]{2}{*}{ liver } & C. albicans - throat & \multirow{2}{*}{$\begin{array}{l}\text { fluconazole, } \\
\text { caspofungin }\end{array}$} & \multirow[t]{2}{*}{ proven IC } \\
\hline & 10.3 & 7.5543 & & $\begin{array}{c}\text { - urine, fluid after liver } \\
\text { re-transplantation, BAL, } \\
\text { blood, aortic abscess, } \\
\text { sputum }\end{array}$ & & \\
\hline \multirow[t]{2}{*}{ VIII } & 52.2 & 50.575 & prepared for a kidney & no culture & - & possible IC \\
\hline & 30.4 & 50.091 & & & & \\
\hline IX & 47.6 & 3.4706 & liver & no culture & - & excluded IC \\
\hline & 46.8 & 2.9706 & & & & \\
\hline & 26.6 & 8.7843 & & & & \\
\hline & 29.6 & 1.8571 & & & & \\
\hline $\mathrm{X}$ & 50,3 & 19.018 & kidney & $2 \times C$. krusei $-2 \times$ & - & proven IC \\
\hline & 34.6 & 26.962 & & $\begin{array}{c}\text { wound, } 5 \times C \text {. glabrata } \\
-4 \times \text { drain, tissue } \\
\text { sample, } C \text {. albicans - } \\
\text { peritoneal fluid }\end{array}$ & & \\
\hline XI & 33.8 & 59.294 & liver & no culture & - & possible IC \\
\hline & 62.8 & 52.149 & & & & \\
\hline & 51.2 & 54.571 & & & & \\
\hline & 52.2 & 60.626 & & & & \\
\hline XII & 59.2 & 2.8286 & liver & no culture & - & excluded IC \\
\hline & 38.8 & 4.4857 & & & & \\
\hline XIII & 120 & 9.7843 & kidney & no culture & fluconazole & probable IC \\
\hline & 82.8 & 8.7843 & & & & \\
\hline
\end{tabular}


Table 1. Continue

\begin{tabular}{|c|c|c|c|c|c|c|}
\hline $\begin{array}{l}\text { Patient } \\
\text { number }\end{array}$ & $\begin{array}{l}\text { Mannan antigen } \\
\text { levels }\end{array}$ & $\begin{array}{c}\text { Anti-mannan } \\
\text { antibody levels }\end{array}$ & $\begin{array}{c}\text { Transplanted } \\
\text { organ }\end{array}$ & Fungal culture & $\begin{array}{l}\text { Antifungal } \\
\text { prophylaxis }\end{array}$ & $\begin{array}{c}\text { Clinical } \\
\text { interpretation }\end{array}$ \\
\hline \multirow[t]{9}{*}{ XIV } & 78.39 & 5.1449 & \multirow[t]{9}{*}{ liver } & \multirow{9}{*}{$\begin{array}{c}2 \times \text { C. albicans }- \\
\text { tongue swab, blood, } \\
2 \times \text { C. glabrata }- \\
2 \times \text { urine }\end{array}$} & \multirow{9}{*}{$\begin{array}{l}\text { fluconazole, } \\
\text { voriconazole, } \\
\text { anidulafungin }\end{array}$} & \multirow{9}{*}{$\begin{array}{c}\text { proven IC, } \\
\text { decrease of } \\
\text { antigenemia } \\
\text { after treatment }\end{array}$} \\
\hline & 152.3 & 9.3478 & & & & \\
\hline & 163.87 & 11.22 & & & & \\
\hline & 3.9 & 11.935 & & & & \\
\hline & 90.3 & 16.101 & & & & \\
\hline & 67.8 & 9.837 & & & & \\
\hline & 75.02 & 13.244 & & & & \\
\hline & 149.5 & 5.0181 & & & & \\
\hline & 50.4 & 3.7353 & & & & \\
\hline \multirow[t]{3}{*}{$X V$} & 44.1 & 50.512 & \multirow{3}{*}{$\begin{array}{l}\text { prepared for a kidney } \\
\text { transplantation }\end{array}$} & \multirow{3}{*}{$\begin{array}{c}1 \times \text { C. albicans }- \\
\text { peritoneal fluid, } \\
3 \times \text { C. glabrata }- \text { stool, } \\
2 \times \text { anal swab }\end{array}$} & \multirow[t]{3}{*}{-} & \multirow[t]{3}{*}{ proven IC } \\
\hline & 85.2 & 24.232 & & & & \\
\hline & 177.5 & 16.042 & & & & \\
\hline \multirow[t]{2}{*}{ XVI } & 52.9 & 12.679 & \multirow[t]{2}{*}{ kidney } & no culture & \multirow[t]{2}{*}{-} & \multirow[t]{2}{*}{ possible IC } \\
\hline & 54.5 & 21.775 & & & & \\
\hline \multirow[t]{2}{*}{ XVII } & 40.9 & 18.417 & \multirow[t]{2}{*}{ kidney } & no culture & \multirow[t]{2}{*}{-} & \multirow[t]{2}{*}{ possible IC } \\
\hline & 34.9 & 16.08 & & & & \\
\hline \multirow[t]{3}{*}{ XVIII } & 443.96 & 7.4457 & \multirow[t]{3}{*}{ kidney } & C. parapsilosis - blood & \multirow[t]{3}{*}{-} & \multirow[t]{3}{*}{ proven IC } \\
\hline & 32.2 & 12.202 & & & & \\
\hline & 53.8 & 9.9457 & & & & \\
\hline \multirow[t]{2}{*}{ XIX } & 36 & 26.416 & \multirow[t]{2}{*}{ liver } & no culture & \multirow[t]{2}{*}{-} & \multirow[t]{2}{*}{ possible IC } \\
\hline & 261.5 & 27.235 & & & & \\
\hline \multirow[t]{2}{*}{$\mathrm{XX}$} & 235.44 & 9.5098 & \multirow[t]{2}{*}{ kidney } & no culture & - & possible IC \\
\hline & 40.7 & 8.1569 & & & & \\
\hline XXI & 300 & 3.2 & prepared for a kidney & C. albicans - sputum & - & probable IC \\
\hline & 312 & 2.314 & & & & \\
\hline XXII & 160 & 0.70588 & prepared for a kidney & no culture & - & probable IC \\
\hline & 185.02 & 0.7647 & & & & \\
\hline & 87.8 & 0.4706 & & & & \\
\hline XXIII & 27.6 & 45.734 & prepared for a kidney & C. albicans - urine & - & probable IC \\
\hline & 42.5 & 64.232 & transplantation & & & \\
\hline & 9.5 & 53.038 & & & & \\
\hline XXIV & 43 & 62.987 & prepared for a kidney & C. albicans - BAL, & - & probable IC \\
\hline & 17 & 39.072 & transplantation & C. krusei-BA & & \\
\hline $\mathrm{XXV}$ & 23.2 & 44.097 & liver & no culture & fluconazole & possible IC \\
\hline & 40.7 & 35.742 & & & & \\
\hline
\end{tabular}


According to EORTC/IFICG guidelines, there are three types of fungal infections in high-risk patients: confirmed, probable and possible [11].

Positive blood cultures, which enable identification of systemic mycoses with manifesting clinical signs, indicating organ invasion, are one of the most important diagnostic criteria; furthermore, additional tests confirm fungal presence in tissues. Additional tests, such as direct microscopic examination confirm the presence of fungi in tissues. Such an infection may be considered proven (confirmed).

Probable invasive mycosis is diagnosed in the presence of clinical signs of infection and the detection of biomarkers (fungal antigen) in at least two serum samples.

Fungal infections in high-risk patients, not presenting any clinical signs, but with positive cultures in material collected from various sites but not blood, should be considered possible $[11,12]$.

ELISA, the used serological methods, detecting highly immunogenic cell wall components - mannan antigens, and also anti-mannan antibodies, are more and more often used in early detection of fungal infections. Serological monitoring of mannan antigen and anti-mannan antibody level in high-risk patients might be a key in detecting or ruling out invasive mycoses [10].

Testing for mannan and anti-mannan antibodies in systemic candidiasis may be performed about six days earlier to positive blood cultures [13].

Many studies emphasise the fact that fungal antigen detection in blood serum in patients under immunosuppression, especially with neutropenia, suggests that adequate antifungal treatment should be administered [14].

Different treatment strategies are used, depending on patient condition and laboratory results. Preventive empirical treatment, used in patients with prolonged neutropenia and fever lasting over five days despite antibiotic treatment, and also with mucosal candidiasis, or with inflammatory lung lesions, is administered in high-risk patients in order to reduce the risk of invasive fungal infections. Patients with positive biomarker results undergo preemptive treatment if fungal biomarkers in their blood serum are regularly monitored $[15,16]$. Targeted therapy is used in patients with a diagnosed fungal infection according to the antimicrobial resistance profile of the pathogen [11, 14, 17].

Treatment in patients with suspected invasive candidiasis as well as in those with a diagnosed infection is difficult and depends on patient condition, infection localisation, and infectious strain. The Infectious Diseases Society of America (IDSA) recommends the following preventive antifungal drugs: fluconazole, itraconazole, and amphotericin $\mathrm{B}[18,19]$. Echinocandins (caspofungin, anidulafungin, micafungin), drugs with a proven high effectiveness in treating Candida spp. infections, are also often used in empirical treatment, besides fluconazole and amphotericin B [19].
Rescue treatment, consisting of a combination of antimycotics or non-standard doses, is used in patients with advanced fungal infections not responding to standard treatments [14].

A thorough assessment of study results demonstrates that serological tests may be used to confirm or rule out invasive candidiasis in high-risk patients. The findings of the present study were analogous to those of foreign research centres $[10,20]$.

The authors declare no conflict of interests.

Study financed by the National Centre for Science (Grant no. N N401 042738).

Project manager: E. Swoboda-Kopeć, $M D, P h D$.

\section{References}

1. Netsvyetayeva I, Sikora M, Gołaś M, et al. (2011): Diagnostyczne aspekty zakażeń grzybiczych u chorych po przeszczepieniu narządów unaczynionych (ze szczególnym uwzględnieniem przeszczepienia nerki). Nowa Klinika. Medycyna Zakażeń 18: 4079-4088.

2. Prella M, Bille J, Pugnale M, et al. (2005): Early diagnosis of invasive candidiasis with mannan antigenemia and antimannan antibodies. Diagn Microbiol Infect Dis 51: 95-101.

3. Pappas PG, Alexander BD, Andes DR, et al. (2010): Invasive fungal infections among organ transplant recipients: results of the Transplant-Associated Infection Surveillance Network (TRANSNET). Clin Infect Dis 50: 1101-1111.

4. Yera H, Sendid B, Francois N, et al. (2001): Contribution of serological tests and blood culture to the early diagnosis of systemic candidiasis. Eur J Clin Microbiol Infect Dis 20: 864-870.

5. Persat F, Topenot R, Piens MA, et al. (2002): Evaluation of different commercial ELISA methods for the serodiagnosis of systemic candidosis. Mycoses 45: 455-460.

6. Kedzierska A, Kochan P, Pietrzyk A, Kedzierska J (2007): Current status of fungal cell wall components in the immunodiagnostics of invasive fungal infections in humans: galactomannan, mannan and (1-->3)-beta-D-glucan antigens. Eur J Clin Microbiol Infect Dis 26: 755-766.

7. Sendid B, Poirot JL, Tabouret M, et al. (2002): Combined detection of mannanaemia and anti-manna antibodies as a strategy for the diagnosis of systemic infection caused by pathogenic Candida species. J Med Microbiol 51: 433-442.

8. Sendid B, Tabouret M, Poirot JL, et al. (1999): New enzyme immunoassays for sensitive detection of circulating Candida albicans mannan and antimannan antibodies: useful combined test for diagnosis of systemic candidiasis. J Clin Microbiol 37: 1510-1517.

9. Sendid B, Caillot D, Baccouch-Humbert B, et al. (2003): Contribution of the Platelia Candida-specific antibody and antigen tests to early diagnosis of systemic Candida tropicalis infection in neutropenic adults. J Clin Microbiol 41: 4551-4558.

10. Ellis M, Al-Ramadi B, Bernsen R, et al. (2009): Prospective evaluation of manna and anti-manna antibodies for diagnosis of invasive Candida infections in patients with neutropenic fever. J Med Microbiol 58: 606-615. 
11. Zielińska E (2003): Kontrowersje dotyczące optymalnej profilaktyki i leczenia zakażeń grzybami w stanach obniżonej odporności. Przegl Epidemiol 57: 299-307.

12. Ascioglu S, Rex JH, de Pauw B, et al. (2002): Defining opportunistic invasive fungal infections in immunocompromised with cancer and hematopoietic stern cell transplants: an international consensus. Clin Infect Dis 34: 7-14.

13. Arendrup MC, Bergmann OJ, Larsson L, et al. (2010): Detection of candidaemia in patients with and without underlying haematological disease. Clin Microbiol Infect 16: 855-862.

14. Nawrot U (2011): Aktualne problemy diagnostyki i terapii grzybic systemowych. Zakażenia 4: 55-62.

15. Wierzbowska A, Pluta A (2011): Profilaktyka i leczenie inwazyjnych zakażeń grzybiczych u chorych z neutropenią według zaleceń ECIL-3. Hematologia 2: 140-148.

16. Biliński P, Seferyńska I, Warzocha K (2008): Diagnostyka i leczenie układowych zakażeń grzybiczych w onkohematologii. Onkol Prakt Klin 4: 15-24.

17. Bondaryk M, Kurzątkowski W, Staniszewska M (2013): Antifungal agents commonly used in the superficial and mucosal candidiasis treatment: mode of action and resistance development. Postep Derm Alergol 29: 293-301.

18. Rex JH, Walsh TJ, Sobel JD, et al. (2000): Practice guidelines for the treatment of candidiasis. Infectious Diseases Society of America. Clin Infect Dis 30: 662-678.

19. Hughes WT, Armstrong D, Bodey GP, et al. (2002): Guidelines for the use of antimicrobial agents in neutropenic patients with cancer. Clin Infect Dis 34: 730-751.

20. White PL, Archer AE, Barnes RA (2005): Comparison of non-culture-based methods for detection of systemic fungal infections, with an emphasis on invasive Candida infections. J Clin Microbiol 43: 2181-2187. 